\title{
Money, Love, and Fragile Reciprocity in Contemporary Havana, Cuba
}

\section{Harkonen, Heidi}

2019-07

Harkonen, H 2019 , ' Money, Love, and Fragile Reciprocity in Contemporary Havana, Cuba '

, Journal of Latin American and Caribbean Anthropology , vol. 24 , no. 2 , pp. 370-387 . https://doi.org/10.1111/jlca.1

http://hdl.handle.net/10138/314669

https://doi.org/10.1111/jlca.12367

acceptedVersion

Downloaded from Helda, University of Helsinki institutional repository.

This is an electronic reprint of the original article.

This reprint may differ from the original in pagination and typographic detail.

Please cite the original version. 
Money, Love, and Fragile Reciprocity in Contemporary Havana, Cuba

By

\title{
Heidi Härkönen
}

\section{NB: This is the accepted manuscript draft, not the final, published version}

\begin{abstract}
Amongst low-income Havana residents, men frequently give money and other forms of material support to women in whom they have a romantic interest. For women, men's material contributions are expressions of responsibility and care. While men share this view to a degree, they sometimes have more ambiguous emotions regarding such practices. These tensions in different views of gendered reciprocity are influenced by large-scale changes that have taken place in Cuban society since the 1990s. Although traditionally state socialism has embraced ideas of gender egalitarianism and women's independent income, the post-Soviet period has seen the emergence of new inequalities, dependencies, and marginalizations that threaten earlier, socialist understandings of intimacy. The importance that women currently place on material wealth in terms of their views of a desirable partner highlights the gendered consequences of Cuba's contemporary economic transformations and their complex interplay with individuals' aspirations for love.
\end{abstract}

KEYWORDS: Cuba, gender, reciprocity, love, money, care, sexuality, kinship, economy, postsocialism, the Caribbean

\section{RESUMEN}

Entre Habaneros de bajos recursos, hombres frecuentemente dan dinero y otras formas de ayuda material a las mujeres en las cuales tienen un interés romántico. Para las mujeres esta ayuda significa que el hombre es responsable y las cuida. Los hombres, aúnque a veces compartan esta visión acerca de sus contribuciones materiales, suelen tener opiniones más ambiguas acerca de lo que esta ayuda significa. Estas tensiones reflejan las transformaciones ocurridas en la sociedad cubana desde los años 90 que han afectado, también, el concepto de la reciprocidad en las relaciones más íntimas. De esta forma, mientras el socialismo ha 
favorecido la igualdad de género, el período post-soviético ha creado nuevos inequidades y marginalizaciones que amenazan concepciones socialistas de intimidad. Esta situación acentúa los efectos diferenciados por género de las transformaciones económicas en la Cuba contemporánea y su complejo enlace con las aspiraciones de amor de los individuos. PALABRAS CLAVES: Cuba, genero, reciprocidad, amor, dinero, cuidado, sexualidad, parentesco, economia, post-socialism, el Caribe

My Cuban friend Yadira once told me about her ex-boyfriend, whom she had at first found attractive; she had quickly changed her mind:

I didn't want to be with him because he was stingy ... he didn't buy me anything. He wasn't like the others who, if you go out, are [like]: "mima, have beer; chicken, do you want another beer?" No ... it was either chicken or beer and to go out with him I had to drink the same beer all night long and later, maybe he bought $[\mathrm{me}]$ another beer after a lot of time ... He didn't let me choose what I wanted from the menu if he took me to eat in a restaurant. No, it was him who chose and it was always the cheapest one. He never bought me a little box of milk or anything. He was a taxi driver and do you know how much money he made? Sometimes even 20 dollars per day! ${ }^{1}$ Once I was with him and he bought a yogurt, the one from the shopin, ${ }^{2}$ for his daughter, and he didn't buy me anything, not even a yogurt or condensed milk. He should have said: "look, mami, take a yogurt". He was very stingy.

Like Yadira, many of my Cuban female friends highlighted the significance of material resources - money, housing, and commodities - to their conceptualization of a desirable partner. ${ }^{3}$ In post-Soviet Havana, as Yadira's statement testifies, a man's inability or unwillingness to make such contributions may land a relationship in trouble. While women often complain about men's failure to fulfill their material expectations, men frequently have doubts about women's motivations, suspecting them of being greedy abusadoras (abusers).

For a long time, anthropological research has shown that money may take on diverse social meanings and play an important role in the reproduction of culturally central values (Bloch and Parry 1989; Brennan 2004; Cattelino 2008; Hutchinson 1996). In the Caribbean, researchers have drawn attention to the multiple ways in which money and economic processes are gendered. Katherine E. Browne (2002) states that in Martinique, women seek to 
secure funds for their kin and household, while men tend to spend more on themselves and on leisure. Discussing the lives of poor Haitian women, Catherine Maternowska (2006: 68-69) argues that because of their responsibility for children, women suffer more than men in terms of the consequences of Haiti's-economic downturn, because they are forced to consent to exploitative sexual and reproductive engagements with only faint hopes of receiving material help from men.

Contemporary Cuba is a particularly fertile place to explore the gendered meanings of money and the tensions that economic change may bring to individuals' intimate relations, which arise because of the particular moral ambiguity that money carries in this rapidly transforming, but still officially socialist society. Cuba differs from other parts of the Caribbean because of its revolutionary state governance that for the last 50 years has rejected market logics and sought to create for individuals an egalitarian access to labor, money, and commodities. The socialist New Man was supposed to be indifferent to material incentives, being instead motivated by feelings of solidarity and social responsibility (Guevara 2005). In a socialist society, where men and women would both be equally engaged in wage labor, gendered dependencies would cease to exist. Nevertheless, in post-Soviet Cuba, political and economic changes are challenging earlier ideas of equality and social solidarity, creating shifts in individuals' understandings of gender relations, love, and sexuality. ${ }^{4}$

Sexual relations among my low-income, racially mixed Habanero friends were often fluid. People were usually not legally married but preferred consensual unions and informal dating relationships. My interlocutors viewed sexuality as a normal part of everyday life, yet often with some ambivalence. Similar tendencies have for a long time been associated with low-income Caribbean people. Since the 1950s, the discussion on Caribbean matrifocality has described gender relations as tension-laden and fragile (Smith 1960). In many ways, my Cuban interlocutors' family relations conformed to earlier discussions of Caribbean matrifocality, whereby relationships are marked by a significant degree of women's autonomy and agency at the same time as women are burdened by carrying alone the responsibility for dependent kin (Smith 1996). ${ }^{5}$ In matrifocality, men are often described as marginal to family relations: absent and negligent of their roles as spouse and father, and engaging in multiple sexual relationships (Clarke 1974).

In terms of Caribbean gender relations, the early structural functionalists highlighted the significance of biological reproduction to masculinity, stating that men's status does not depend on economic resources (Barrow 1998: 354-356). However, later research, such as 
work by Christine Barrow (1998), has criticized the idea of Caribbean male marginality, observing that men maintain affective relationships with their female kin as sons, uncles, and brothers. Barrow and others have shown how relationships between men and women in the Caribbean rely on gendered reciprocity, whereby women contribute nurture and men are expected to make material contributions. As a result of these forms of reciprocity, money and material wealth play an important role in men's relationships and in ideas of desirable masculinity.

In contemporary Havana, men's material support for their female partners can be understood as a gendered mode of reciprocal care that plays a central emotional role in relationships. To many women, and often also to men, such material contributions convey ideas of a man as responsible, caring, and loving. My understanding of gendered care in my Cuban interlocutors' relationships draws both on classical interpretations of reciprocity and more recent discussions on the intermingling of love/affect and material exchanges. For Marcel Mauss (1999), reciprocity represents the social aspect of exchange, where - as opposed to material gain - the social bond that ties individuals to each other is emphasized. ${ }^{6}$ In revolutionary Cuba, where since 1959 the government has rejected commodified understandings of the economy and social relations, the Maussian idea of reciprocity resonates significantly with socialist political ideals of a humane society. ${ }^{7}$ Traditionally, reciprocity has been important to Cubans in various practical ways (Andaya 2009; Lewis et al., 1977; Rosendahl 1997).

Maussian reciprocity is normative and binding: a gift needs to be obligatorily reciprocated and material exchanges carry the potential to create relationships that have continuity over time (Mauss 1999). Christopher Gregory (1997: 65) conveys a similar idea with his concept of "reciprocal recognition," presupposing an "agreement as to the meaning of a transaction.” Gregory (1997: 65) states: “This agreement is more likely to occur among insiders who because of relations of contiguity have been able to develop it over time and who are more likely to have a mutual interest in maintaining their relationship in the future." Mutual interest suggests a reciprocal recognition is more likely to occur between persons who at some level share an interpretative framework for defining the meaning of the exchange and emphasize the creation of the relationship the exchange enables. In a similar vein, Jennifer Cole (2009: 115) approaches reciprocity as the social recognition of a relationship. My understanding of reciprocal care and love in my interlocutors' relationships comes close to Cole's (2009: 113) definition of fitiavina — love, in rural Madagascar: "to take resources and 
put them towards the well-being of another is to nurture, protect, and give of oneself. It is the primary way to create attachment. In fitiavina, love and material support are ideally fused." Amongst low-income Habaneros, reciprocal care involves gendered, nurturing, and material practices for mutual well-being, ranging from providing someone with material contributions to feeding, offering emotional support, or performing physical labor.

However, reciprocity is not static. In situations of large-scale political and economic transformation, people's views of love, care, and reciprocity may change. Recently, many scholars (Cabezas 2009; Fernandez 2010; Stout 2014) have shown that in post-Soviet Cuba, where state contributions to individuals are being rapidly dismantled, affective relations are plagued by suspicions of commodification at the same time as intensifying inequalities challenge the official rhetoric of socialist egalitarianism. Among my low-income interlocutors, who lacked new sources of income such as remittances or involvement in the lucrative tourism industry, these shifts in understandings of intimacy were particularly pronounced. My research adds to the scholarship on contemporary Cuba by showing how in the midst of the insecurities of life in post-Soviet Cuba, the current tensions in Habaneros' love relations both draw upon and challenge understandings of reciprocity. Due to the centrality of money to their views of gendered reciprocity, low-income Cubans experience new dependencies and marginalizations in their love relations that threaten their fundamental ideas of social existence.

\section{Fieldwork in Havana}

My research draws on 22 months of ethnographic research amongst racially mixed, lowincome Havana residents since 2003. During my doctoral research in 2007-2008, I lived for nine months with a Cuban family I have known since my first fieldwork period. I followed people's kin relations and other social networks - lovers, friends, and neighbors - mainly in two locations: in Centro Habana and in a residential neighborhood in eastern Havana. My research took place in these two neighborhoods because the Cuban family (that over the years has become "my Cuban family") and their kin lived mainly in these two locations. I did not focus on the neighborhoods as such, but followed the course of my interlocutors' relationships as they moved about their everyday lives. 
Many of my friends were originally from east Cuba and had arrived in Havana from the 1970s onwards. Some were self-employed but earned little, selling coffee by the roadside, for instance; others held state jobs with low salaries. Two men were engaged in on-and-off construction work and one man was employed in the - in Cuban terms - lucrative tourist industry. The women held jobs as teachers and secretaries and made money by selling pastries and giving manicures. Most people's income conformed to Cuba's average monthly salary of 15 USD in 2007.

With a focus on the interplay amongst gender, kinship, and state policies over the life course, I conducted participant observation, held open-ended interviews, and collected diverse forms of state discourse. I conducted 65 interviews with ordinary men and women, ranging from young people to elderly participants. I also interviewed 25 "state officials" and noted down informal statements. I paid particular attention to the observation of people's day-to-day interactions, exchanges, and caring practices, following Bourdieu's (1990) insights that many fundamental aspects of everyday life are often not verbalized. I participated in people's daily chores: helped paint houses and do the laundry, for instance; I also went to discos and sat on sofas drinking cafecitos. I observed child care and elderly care and people's use of money to understand the relationship between everyday care and Cuba's economic processes. Whereas my observation of daily life focused on the people in the two neighborhoods and their social contacts - amounting to some thirty households - I expanded my research by collecting information from various state and non-state contexts. To understand ideas about the life course, I visited state institutions such as maternity homes, and observed life cycle rituals such as Catholic baptisms. ${ }^{8}$ I interviewed experts such as state divorce lawyers. To account for Cuba's political environment, I observed state rituals such as the May Day Parade and analyzed media material. Finally, to understand care as an aspect of love, I talked with men and women about their hopes, dreams, and disappointments and witnessed love dramas that often revolved around questions of material contributions in postSoviet Havana.

\section{Cuba in the Post-Soviet Period}

The disintegration of the Soviet Union in the 1990s transformed Cuba in many ways: in part, the government was obliged to make concessions in relation to the country's socialist 
ideology, such as opening the country to mass international tourism, allowing for the formation of small private enterprises, and legalizing the double currency system (Eckstein 1994). Since this "dollarization" (Roland 2011: 51), a greater number of material items have become available to Cubans only by paying for them with money - in official state shops or in the informal economy - as opposed to the previous possibility of receiving them as state subsidies, either through the socialist rationing system or as rewards for exemplary work performance. My interlocutors felt money had become more important than it had been during the post-Soviet era. An elderly woman remarked in relation to Cuba in the 1980s: "in that era there was no money." For many, the time before the 1990s represented an era of plenty when the state provided Cubans with nearly everything they needed (Holbraad 2014; Rosendahl 1997). Now people need money to access day-to-day staples. At the same time, there has been an increase in Cubans' possibilities and desires for consumption, despite shop offerings continuing to be meager and over-priced given average wages (Hodge 2005).

Many researchers have shown these transformations are connected to increased inequalities of class and race in post-Soviet Cuba (Cabezas 2009; de la Fuente 2001; Martinez 2013; Roland 2011). It is likely that my friends' low-income status shapes the centrality of material issues to their negotiation of romantic attachments. The liberalizing of the economy, which has included the dismantling of many state services, contributions, and regulations, has brought material wealth to some Cubans through remittances and opportunities in the tourist industry, while others have faced increased struggles to get by. Most of my interlocutors lacked the remittances that allow many privileged and middle-class Cubans to subsist and even live comfortably in today's Havana. The challenges they faced in their relationships are therefore emblematic of the emergence of heightened inequalities of wealth in post-Soviet Cuba.

\section{State Conceptualizations of Love and Money}

One of the central ideas guiding revolutionary gender policies was that women's full participation in the labor force was supposed to bring about gender equality and promote women's independence from men (Hamilton 2012: 27-36; Randall 1998). The revolutionaries expected social egalitarianism and independent income to guarantee love relations that were free of material interest. This conceptualization draws on the work of 
Engels (2004), who argued that in a socialist society, love would be devoid of material dependencies and asymmetries.

Combined with state efforts to promote love relations across pre-revolutionary divides such as race, class, age, and place of residence (Díaz Tenorio 1993), state policy set out to pursue egalitarian marital bonds based on a couple's mutual attraction. Socialist gender policy was thus characterized by attempts to define the appropriate divide between love and money and between relationships motivated by passion and material interests. This policy reflects a modern idea of romantic love as "pure" passion - that is, emotion detached from reason and the material world of exchange (Hirsch and Wardlow 2006).

Although Cuba's socialist gender policies have undergone significant changes over the years, in contemporary society, such state policy is observable, for instance, in the educational television "advertisements" of the Cuban Women's Federation (Federación de Mujeres Cubanas, FMC), which urge women to choose "education" and "respect" over staying in an unsatisfactory relationship because of the material safety such unions may offer.

“Cuando una mujer”, Cubavisión, 5 June, 2007

A woman says: "Infidelity is the major cause of conflict in a relationship. Even though both women and men cheat, men continue to practice infidelity more often, due to a model of machismo."

Two women talk; a friend gives advice to a woman, telling her not to leave her partner: "because you're not a woman used to the hard life."

She tells her it would be best to forget her partner's infidelity because things are going well materially. Next, we see the woman's partner arriving home from work. The phone rings and the man answers, telling the caller he will arrive shortly.

The woman starts shouting: "You're cheating on me!"

The man says: "I have a meeting," ignoring his partner's anger.

He states: "Serve me the food, or if not, there is the door!"

The woman does not leave: 'I can't be egoistic, I can't go to my parents' house and [looks at her little daughter] the girl..."

Another female friend says to the woman: "You can finish your studies, so that people respect you, so that they don't crush you." 
At the end of the broadcast the narrator states: "Infidelity is a cause of life and death in the era of AIDS."

Whilst forming part of a public health campaign, such broadcasts also seek to promote a model of gender relations. I do not know when the FMC started to air these broadcasts, but it is likely that they are an example of campaigning through which state authorities tried to curtail what they regarded as increased societal materialism in the 1990s (see Hodge 2001: 25; 2005: 13). This broadcast urges women to leave men who treat them badly, even though they may provide them with material security. Instead of material considerations, women need to prioritize personal growth, integrity, and education. In practice, however, things are often less straightforward than what is depicted in such announcements. In post-Soviet Cuba, because of the low salaries in nearly all professional areas except tourism, education offers women (and men) few genuine possibilities for enjoying a satisfactory independent life. Many young Cubans view education as useless for social ascendance because it poses limited chances for gaining improved economic status. The broadcasts fail to acknowledge how practical life differs from socialist ideals in post-Soviet Cuba.

Discussing how both individuals and the Cuban media express concern about the tendency for young people to emphasize material interest in their choice of a partner, Elise Andaya (2013) argues that nostalgia for a "disinterested love" in contemporary Cuba reveals anxiety over new forms of hierarchy and inequality that value entrepreneurial activities, economic prosperity, and leisurely consumption. I agree with Andaya that Cuba's new economic order has created significant anxiety that is reflected in the narratives about "material interests" in relationships. However, at the same time, the emphasis my female friends placed on men's material resources in their views of a desirable partner, and the struggles that many of my male interlocutors had in fulfilling women's expectations, suggest that among low-income Habaneros, this is not just about discursive change. Cuba's structural developments have eroded socialist ideas of gender equality and intensified men's role as providers of material care, creating the risk that some men will become marginalized in their aspirations of love.

\section{Negotiating Love, Attraction, and Reciprocity in Contemporary Havana}


Among my Cuban friends, men frequently gave money and other forms of material contribution to their partners or to the women with whom they desired to initiate a relationship. People viewed such contributions as an intrinsic part of love relations and conceptualized them as "little gifts" (regalitos). These gifts varied greatly, ranging from a bar of soap to a laptop. While Yoel, a poor migrant from east Cuba, courted his neighbor by giving her a tube of toothpaste, Rosa's wealthy boyfriend bought her a DVD player, a laptop, and relatively large sums of money (50-70 CUC) for her everyday needs.

Yadira's statement on her new boyfriend exemplifies the way material wealth is connected to ideas of caring responsibility: "He is a responsible guy ... he gives me money for transportation, he buys beer, he is a muchacho luchador [fighter], he finds money; he is responsible even though he is young." For Yadira and her friends, the ability to acquire money for everyday needs (even if this is sometimes just beer) and a willingness to share his income with his partner, are markers of a caring, responsible man.

Although there are men who have relations with women where money flows from the woman to the man, they are regarded as an inversion of how relationships should work. Some men felt uncomfortable with this type of gendered exchange. When Carlos was dating a woman who was considerably wealthier than he was, he wanted to end the relationship. He said he did not like the woman because she was "muy metalizada" (very interested in material wealth). Another man explained the term like this: "a woman who does not need a man for anything, who has her house, has money." A woman who supports a man inverts the normal conceptualization of gendered reciprocity and complementary dependency that should prevail between lovers. For women, to receive money and material support from their partner represents the correct way a man should behave towards them. However, for a man, becoming dependent on his partner in terms of money, housing, and material help puts at risk an important aspect of his masculinity.

In my Habanero friends' relationships, money is gendered; it is something men are expected to contribute to women in a system of reciprocal exchange in which women respond with nurture, sexual "access," and children. ${ }^{9}$ These contributions do not mean women would not desire sexual relationships with men if it were not for the money: none of my female interlocutors engaged in sex work and women sometimes had short-term sexual engagements with men who did not give them money. Still, in the context of post-Soviet Cuba's heightened monetization, money has become a necessary object for men to create relationships-both sexual and non-sexual. While women also have their own money, money 
is the means by which a man expresses a romantic interest towards a woman, by giving her little gifts and taking her out to eat, for drinks, or dancing. As exemplified by Yadira's rejection of her ex-boyfriend because he was "stingy" and her pleasure with her new partner because of his material "responsibility," it is through her partner's material contributions that she assesses whether he is a trustworthy man and someone who can help her in life.

While Cuba has two official currencies that differ significantly in value, and in the past, researchers have noted that Cubans yearn for the dollar in particular (Hodge 2001), my female friends did not care to any great extent whether the gifts they received came in CUPs or in CUCs. CUCs are generally more valued because their buying power is greater, but since the two currencies are interchangeable, people were mostly interested in the quantity, not the kind, of money. They often referred to CUCs and CUPs as "dinero" (money). In their daily life, my interlocutors operated primarily in the CUP economy, reflecting their low-income position.

Although amongst my interlocutors, money is gendered in the sense that in a sexual or love relationship it primarily flows from men to women, there was no clear gender difference in terms of the two currencies; both men and women used CUPs and CUCs in their daily life. With regard to the gifts that women received from men, individual situations varied: whereas Yadira's boyfriend usually gave her CUPs, Rosa's wealthy partner gave her CUCs, amounting to much more money than Yadira's gifts.

While Rosa always managed to find wealthy partners, Yadira often struggled to encounter men who would give her the kinds of gifts she was hoping for. My female interlocutors' expectations of men's material care were expressed even more clearly in situations where a man did not give his partner money or other material contributions. Such behavior made women suspect that the man did not work, that he was trying to profit from his partner, or was spending his money on another woman. ${ }^{10} \mathrm{~A}$ man who does not give gifts to his partner risked losing her because women are often unwilling to maintain a relationship with such a man, inferring a lack of interest. The lack of male contributions often plays a major role in break-ups, although it may not be the only reason for a woman's desire to terminate a relationship. When Yadira's partner Livian lost his job and became unable to give her his usual monthly contribution (100 pesos/4.25 USD) and take her out on the weekends, Yadira wanted to terminate the relationship. As Livian was still in love with her, he tried to make Yadira change her mind by doing construction work on her home. Nevertheless, Yadira was unwavering in her decision to end the relationship and Livian was soon left alone. Even 
though Livian tried to replace his earlier monetary contributions with another form of reciprocal help, for Yadira, his lack of money meant their relationship was unquestionably over.

Sometimes women made a contrast between "liking" (gustar) a man and entering into a relationship with him primarily because of his material contributions. Talía maintained a romantic involvement with Yunior, whom she did not find attractive, but she appreciated the regular gifts of food and money he was able to offer her. She did not have sex with him, but kept him company and sometimes kissed him. She also maintained a friendly relationship with his family, helped him occasionally with the running of small errands, and she once lent him money when he became unemployed. There was clearly reciprocity in the relationship, although their interactions often left Yunior unhappy.

To a large extent, my male friends shared the view of their material contributions to women as an expression of love and reciprocal care in a relationship and connected it with responsible masculinity. In describing his efforts to win back his ex-partner Rosa, Carlos stated: "I maintained Rosa and when we had already separated, I still took her some things to fix her home." Even after their break-up, Carlos tried to reclaim his love of Rosa via material contributions. However, Rosa had already met a wealthy new partner and rejected Carlos's gifts, as a way to show him their love was over. At the moment of terminating her relationship, Rosa rejected Carlos's contributions as a way to discard his efforts to reestablish the reciprocity that had earlier prevailed between them.

Men sometimes expressed annoyance about the number of claims their partners made on them. After Yunior had provided the money for Talía's birthday celebration at the beach and bought beer and food for the party (leaving him penniless), he was annoyed when Talía kept on pushing him to buy her a pair of shoes. Men usually became irritated with women's requests when a relationship was also afflicted by other problems or after a woman had ended the relationship. However, even when expressing such views, men never completely denied women's rights to make material claims on them. Rather, they complained about the number of claims: 'women expect too much.' In their relationships, both men and women conceptualize love and care as expressed through material contributions, but the negotiation of a properly balanced reciprocity is important. Between Talía and Yunior, his contributions outweighed her commitment to the relationship; she constantly denied him a more intimate form of engagement by refusing to have sex with him, causing his annoyance with too many demands on her part. ${ }^{11}$ 
For a man to suggest his partner is cultivating a relationship with him primarily for material reasons entails several moral ambiguities. My interlocutors valued generosity and saw it as a highly desirable male quality. A man who tried to deny money to his partner soon faced accusations of stinginess, which most men wanted to avoid. When Yadira and I went out with Yankiel, a state-employed but relatively well-off man, ${ }^{12}$ she only told him on the spot that it was her birthday; despite having bought us several drinks, he responded: "You should have told me it was your birthday and I would have brought more money." ${ }^{13}$ Being tight with his money may mean that others question a man's ability to make a living, leading in the worst case to a description of him as "muerto-de-hambre" (starving-to-death) —another depiction my friends found undesirable. Finding ways to make money, knowing how to "resolve problems," accompanied by a certain ideal notion of being a male provider, are all qualities connected with desirable masculinity.

For a man to propose that his partner is a greedy abusadora who exploits his material contributions without any (social, emotional, or erotic) engagement on her part raises suspicions about his ability to be a "real man" (machote) who does not take ill treatment from anyone. When Yanet had neglected her boyfriend by missing appointments, he stated: 'I'm annoyed, since I know she doesn't think of me and I think of her." My friends regarded relationships that were devoid of reciprocity, or characterized by heavily one-sided contributions, as abusive.

To be placed in the position of being a "victim" does not fit well with my interlocutors' ideas of masculinity. They valued male assertiveness and the ability to be in control. As Maikel observed: "A Latino likes to have all the reigns in his hand: he wants everybody to know you're no longer free, that you have a master (un dueño)." Maikel's view is shaped by ideas of machismo and respect: that a man knows how to demand respect and does not let others walk all over him. ${ }^{14}$ A man who lets others take advantage of him is not worthy of respect because he does not know how to earn it. Thus, suggesting a woman is in charge of what happens in a relationship questions male assertiveness, leading to a perception of the man as weak and lacking masculinity.

Moreover, emphasizing a man's one-sided contributions in a relationship may suggest a man is so unattractive that he can only charm women with his money. Once we saw a man in the street who in Yadira's view was very unattractive. She stated: "Look how fat he is; he will have to pay for someone to have sex with him because no one is going to sleep with him without money, even though he is young." The focus on one-sided contributions denies an 
erotic attraction on the woman's part, and carries the potential to question a man's masculinity, because my interlocutors' conceptualization of gender involves mutual heterosexual desirability as a crucial aspect of both femininity and masculinity (Härkönen 2016; Lundgren 2011).

Amongst my low-income Cuban friends, both men and women share a view of desirable masculinity as shaped by a man's ability to provide material contributions to his partner, but they often disagree on what constitutes appropriately balanced reciprocity. Such tensions become exacerbated in the context of post-Soviet Cuba's intensified monetization and heightened inequalities of wealth.

\section{The Marginalization of Love in Post-Soviet Havana}

Even though the Cuban revolution was supposed to counter such tendencies, the significance of material wealth in relation to men's ability to create relationships has gained prominence since the 1990s. In her description of Cuban gender relations in the 1970s, Margaret Randall (2003: 403) notes: "Speaking with young people, you won't find many who see their futures dependent on marriage or a future husband's career. Their central goal in life is their own development and their potential contribution to society." Similarly, in her account of eastern Cuba during the 1980s, Mona Rosendahl (1997: 69) states that even though women expect material contributions from their partners, a man's wealth is not overly significant in terms of his attractiveness to women. Instead, women stress the importance of finding a "good" man who takes care of them and respects them (Rosendahl 1997: 69). However, in contemporary Havana, in the midst of declining state contributions and the heightened monetization of everyday life, regular monetary contributions to his partner are what make a man "good" amongst my low-income friends.

Recently, several studies have observed the complex relationship between affect and material pragmatism in post-Soviet Cuba. Silje Lundgren (2011: 64) suggests that her middle-class interlocutors differentiate between relations based on "an ideal of 'true love' and those based on economic interest," although women expect desirable partners to have some economic stability. Others, such as Amalia Cabezas (2009: 168), see a wide range of relationships as involving "some commodified aspects blended with intimacy." Megan Daigle (2015), Nadine Fernandez (2010), and Kaifa L. Roland (2011) have drawn attention to 
how views of commodified relationships reflect post-Soviet Cuba's intensified racial inequalities, at the same time as relationships with wealthier partners may offer traditionally marginalized persons new possibilities for agency and social mobility.

If we understand love as "the sentiments of attachment and affiliation that bind people to one another" (Cole and Thomas 2009: 2), material contributions often become the way to express and prove the existence of such bonds. Differing from Lundgren's middle-class interlocutors, my Habanero friends never spoke of "true love." While men could sometimes declare their love for their partner, saying, for instance, "she is the love of my life," it was not typical for women to use the term "love" (amor) to describe their attachments to men. At best, they might say they "liked" someone (me gusta) but this attraction was always shaped by being pleased with material help or the forms of entertainment a man was able to offer. A man's material gifts to his partner thereby became an intrinsic aspect of his attractiveness and a proof of his love. At the same time, although women may not speak of love as such, they may stay cooking, cleaning, and caring for a man for years, showing love via everyday acts of nurture.

Norma and José are an elderly couple that have been together for over ten years. I never heard Norma say she loves José but she was always attuned to his well-being; she made sure he had enough to eat and took care of his health. On one occasion, after a glass of rum, Norma sat in José's lap and caressed his cheek, confessing to me, "I do not plan to leave José anymore." While Norma never verbally stated her love for José, her love materialized in her committed caring practices for José's benefit. Love, therefore, is not primarily a verbal issue that is expressed via speech. Rather, love becomes visible in everyday care and nurture and in material pragmatics. This tangible understanding of love is probably a reflection of my friends' low-income positions, which makes everyday care a crucial aspect of showing affection.

Among Habaneros, the contemporary dynamics of gendered exchange create new marginalizations and hierarchies of love that contest earlier socialist ideas of equality and intimacy. Wealthier men maintained an advantage in attracting women, and some men saw this as a constant threat - that another, richer man might appear and offer more to their partner. Yasser, a man in a low-paying state job, told me he constantly felt anxious and jealous in his relationship because he knew how much his partner Dailet would like to migrate abroad. Yasser was afraid Dailet would meet a foreigner who would promise to take her with him. Due to the importance that my female friends placed on their partners' material 
contributions, this fear seemed reasonable: soon after, Yasser was left alone because Dailet entered into a relationship with a wealthy Cuban man who received regular remittances from the United States. While it is easy to speculate that Dailet never loved Yasser, she had seemed happy and in love with him when they were together. Nevertheless, love is unpredictable and relationships may change rapidly.

The centrality of material wealth in my interlocutors' views about love, care, and gendered reciprocity, both reflects and creates new inequalities in post-Soviet Cuba. While some men-like Rosa's wealthy new partner who receives remittances and is able to offer his women laptops and DVD players - continuously have a partner, others - such as my poor, state-employed artist friend Osmael—struggle to find a woman willing to maintain a relationship with a man who is constantly broke.

It would be too simplistic to see this gendered dynamic as an indication of women being "greedy." Rather, the issue is better examined in the overall context of my Cuban friends' kinship relations. Women continue to maintain significantly greater responsibility for dependent kin than men (Härkönen 2016). Women usually share the few resources they have with wider networks of kin whilst simultaneously trying to secure their children's material well-being (Andaya 2014). However, women's emphasis on their male partners' material contributions may highlight more dichotomized understandings of intimacy if it increases the pressure women feel to partner with men who-apart from their material resources - have little appeal in terms of other factors of attractiveness (such as good looks, dance skills, and courteous behavior).

This situation, which highlights hierarchies and the marginalization of love, is reminiscent of the findings of Stout (2014), who argues that Cubans criticize and seek to resist market logics in their love relations, although in practice such logics often threaten their understandings of intimacy. Amongst my Habanero friends, both men and women seek to resist dichotomized understandings of relationships in their conceptualization of love and money. Nevertheless, Cuba's new realities were increasing their contestations for the appropriate forms of reciprocity and these threaten to marginalize from love those men who are unable to fulfill women's expectations of material care.

\section{Conclusion}


In post-Soviet Cuba, the new importance of money and the dismantling of state services have led low-income Cubans to experience new dependencies in their relationships. Despite years of state egalitarianism and an ideology that has emphasized women's economic independence and engagement in wage labor, low-income Habanera women make significant material demands on men in their love relations. Even though my Cuban friends' understandings of gender relations in many ways emphasized women's autonomy and agency, and all my female interlocutors were engaged in economic activities that earned them some money of their own, women relied significantly on their male partners' contributions in their efforts to secure their own and loved ones' well-being. These dependencies contest socialist ideas of gender equality and create shifts in practices of care in ways that threaten earlier understandings of love, intimacy, and reciprocity.

As a result of Habaneros' suspicions and fears about material and emotional exploitation, the reciprocity in their relationships is fragile and contested, and different from the compelling, enduring reciprocity described by Mauss (1999) and Gregory $(1982,1997)$. In post-Soviet Havana, low-income Cubans' relations of reciprocity are under constant threat from the island's intensifying inequalities that are increasingly undermining socialist ideas of humane social interactions. Nevertheless, relationships have not simply become commodified: my interlocutors still drew on reciprocity in their understandings of their relations. Their reciprocity is a subtle negotiation that at times becomes deviated, distorted, and deformed but people still do not regard their exchanges as commodified.

At the same time, the current role of money in low-income Habaneros' understandings of gendered reciprocity creates new marginalizations of love. Contemporary Cuba's economic changes favor those who are well connected in terms of foreign remittances and the local tourist industry. In contrast, for many of my male friends, who struggle to get by in low-paying state jobs or in random, informal economic engagements, their lack of money threatens to leave them without a partner and deprive them of crucially important social connections that people usually take for granted. While Cuba's on-going re-structuring of the state economy and politics creates increased opportunities for some, it puts others at risk of a more permanent exclusion from the core fields of sociability that are vital for existence.

\section{Acknowledgements}


Fieldwork in Cuba was funded by the Finnish Cultural Foundation, the Oskar Öflund Foundation, and the Ryoichi Sasakawa Young Leaders' Fellowship Fund. The writing of this article was made possible by funding from the Academy of Finland. I am grateful to Valerio Simoni, Amalia Cabezas, and the anonymous JLACA reviewers. A special thanks to my Cuban friends for letting me share their lives.

\section{References cited}

Andaya, Elise. 2009. "The Gift of Health: Cuban Medical Practice, Socialist Morality, and the Post-Soviet Economy." Medical Anthropology Quarterly 23 (4): 357-374.

—. 2013. “"'Relationships and Money, Money and Relationships”: Anxieties around Partner Choice and Changing Economies in Post-Soviet Cuba." Feminist Studies 39:728-755.

-2014. Conceiving Cuba: Reproduction, Women, and the State in the Post-Soviet Era. New Brunswick: Rutgers University Press.

Barrow, Christine. 1998. “Caribbean Masculinity and Family: Revisiting 'Marginality' and 'Reputation'." In Caribbean Portraits: Essays on Gender Ideologies and Identities, edited by Christine Barrow, 339-358. Kingston: Ian Randle.

Bourdieu, Pierre. 1990. The Logic of Practice. Cambridge: Polity Press.

Brennan, Denise. 2004. What's Love Got To Do With It? Transnational Desires and Sex Tourism in the Dominican Republic. Durham: Duke University Press.

Browne, Katherine E. 2002. Creole Economics: Caribbean Cunning under the French Flag. Austin: University of Texas Press.

Cabezas, Amalia L. 2009. Economies of Desire: Sex and Tourism in Cuba and the Dominican Republic. Philadelphia: Temple University Press.

Cattelino, Jessica R. 2008. High Stakes: Florida Seminole Gaming and Sovereignty. Durham: Duke University Press.

Clarke, Edith. (1957) 1974. My Mother who Fathered Me: A Study of the Family in Three Selected Communities in Jamaica. London: Allen \& Unwin. 
Cole, Jennifer. 2009. "Love, Money, and Economies of Intimacy in Tamatave, Madagascar." In Love in Africa, edited by Jennifer Cole and Lynn M. Thomas, 109-134. Chicago: University of Chicago Press.

Cole, Jennifer and Lynn M. Thomas. 2009. Introduction. Love in Africa, edited by Jennifer Cole and Lynn M. Thomas. Chicago: University of Chicago Press.

Daigle, Megan. 2015. From Cuba with Love: Sex and Money in the Twenty-First Century. Oakland: University of California Press.

de la Fuente, Alejandro. 2001. 'Recreating Racism: Race and Discrimination in Cuba's 'Special Period'." Socialism and Democracy 15:65-91.

Díaz Tenorio, Maréleen. 1993. Uniones Consensuales de Cuba [Consensual Unions in Cuba]. Havana: Centro de Investigaciones Psicológicas y Sociológicas.

Eckstein, Susan Eva. 1994. Back from the Future: Cuba under Castro. Princeton: Princeton University Press.

Engels, Friedrich. (1884) 2004. The Origin of the Family, Private Property and the State: In the Light of Researches of Lewis H. Morgan. Newtown: Resistance Books.

Fernandez, Nadine. 2010. Revolutionizing Romance: Interracial Couples in Contemporary Cuba. New Brunswick: Rutgers University Press.

Gregory, Christopher A. 1982. Gifts and Commodities. London: Academic Press.

- 1997. Savage Money: The Anthropology and Politics of Commodity Exchange. Amsterdam: Harwood Academic Publishers.

Guevara, Ernesto Che. (1965) 2005. El Socialismo y el Hombre en Cuba [Socialism and Man in Cuba]. Melbourne: Ocean Press.

Hamilton, Carrie. 2012. Sexual Revolutions in Cuba: Passion, Politics and Memory. Chapel Hill: University of North Carolina Press.

Hirsch, Jennifer S. and Holly Wardlow. 2006. Introduction. Modern Loves: The Anthropology of Romantic Courtship and Companionate Marriage, edited by Jennifer S. Hirsch and Holly Wardlow. Ann Arbor: University of Michigan Press.

Hodge, Derrick. 2001. "Colonization of the Cuban Body: The Growth of Male Sex Work in Havana." NACLA Report on the Americas 34:20-28. 
2005. "Sex Workers of Havana: The Lure of Things." NACLA Report on the Americas 38:12-15.

Holbraad, Martin. 2014. "The Values of Money: Economies of Need in Contemporary Cuba." Suomen Antropologi: Journal of the Finnish Anthropological Society 39 (2): 519.

Hutchinson, Sharon E. 1996. Nuer Dilemmas: Coping with Money, War, and the State. Berkeley: University of California Press.

Härkönen, Heidi. 2016. Kinship, Love, and Life Cycle in Contemporary Havana, Cuba: To Not Die Alone. New York: Palgrave Macmillan.

Lewis, Oscar, Ruth M. Lewis, and Susan M. Rigdon. 1977. Four Women: Living the Revolution: An Oral history of Contemporary Cuba. Urbana: University of Illinois Press.

Lundgren, Silje. "Heterosexual Havana: Ideals and Hierarchies of Gender and Sexuality in Contemporary Cuba.” PhD diss., Uppsala University, 2011.

Martinez, Hope 2013. "From Social Good to Commodity, Reproducing Economic Inequalities." Anthropology News 54:11-37.

Martinez-Alier, Verena. 1974. Marriage, Class and Colour in Nineteenth Century Cuba: A Study of Racial Attitudes and Sexual Values in a Slave Society. London: Cambridge University Press.

Maternowska, Catherine M. 2006. Reproducing Inequities: Poverty and the Politics of Population in Haiti. New Brunswick: Rutgers University Press.

Maurer, Bill. 2006. "The Anthropology of Money.” Annual Review of Anthropology 35:1536.

Mauss, Marcel. (1925) 1999. Lahja [The Gift]. Translated by Jouko Nurmiainen and Jyrki Hakapää. Helsinki: Tutkijaliitto.

Parry, Jonathan and Maurice Bloch, eds. 1989. Money and the Morality of Exchange. New York: Cambridge University Press.

Pertierra, Anna C. 2008. "En Casa: Women and Households in Post-Soviet Cuba." Journal of Latin American Studies 40:743-67. 
Randall, Margaret. 1998. "Review of Sex and Revolution: Women in Socialist Cuba." Science \& Society 62:604-606.

_. (1981) 2003. “The Family Code.” In The Cuba Reader: History, Culture, Politics, edited by A. Chomsky, B. Carr and P. M. Smorkaloff, 399-405. Durham: Duke University Press.

Roland, Kaifa L. 2011. Cuban Color in Tourism and La Lucha: An Ethnography of Racial Meanings. New York: Oxford University Press.

Rosendahl, Mona. 1997. Inside the Revolution: Everyday Life in Socialist Cuba. Ithaca: Cornell University Press.

Safa, Helen. 2005. "The Matrifocal Family and Patriarchal Ideology in Cuba and the Caribbean." Journal of Latin American Anthropology 10 (2): 314-338.

Smith, Raymond T. (1957) 1960. "The Family in the Caribbean." In Caribbean Studies: A Symposium, edited by Vera Robin, 67-79. Seattle: University of Washington Press.

_ 1996. The Matrifocal Family: Power, Pluralism and Politics. New York: Routledge.

Stout, Noelle. 2014. After Love: Queer Intimacy and Erotic Economies in Post-Soviet Cuba. Durham: Duke University Press.

Wardlow, Holly. 2006. Wayward Women: Sexuality and Agency in a New Guinea Society. Berkeley: University of California Press.

Zelizer, Viviana A. 2005. The Purchase of Intimacy. Princeton: Princeton University Press.

\section{Notes}

${ }^{1}$ Cuba has two official currencies: the Cuban peso (CUP) and the convertible peso (CUC). Between 1993 and 2004, the United States Dollar (USD) was an official currency in Cuba but the CUC replaced it in 2004. One CUC equals 24 CUPs and CUC is of equal value to the USD. Cubans still often speak of "dollars" in reference to the CUC. The average monthly salary was about 15 CUC (360 CUP) during my fieldwork in 2007/08.

${ }^{2}$ A state store operating in the expensive CUC currency.

${ }^{3}$ All names of research participants are pseudonyms. 
${ }^{4}$ I use the term "love" in this article to refer to my interlocutors' heterosexual relationships that included at least one partner's sexual or "romantic" attraction towards the other. Love amongst kin differs from the relationships discussed here.

${ }^{5}$ Although matrifocality has traditionally been viewed as an Afro-Caribbean family form that is widespread in the English-speaking Caribbean, Helen Safa (2005) maintains the revolution has increased the prevalence of matrifocal kinship in Cuba. In addition to my own work (Härkönen 2016), Elise Andaya (2014: 76-77) and Anna Pertierra (2008) see Cuban kinship relations as characterized by relationships similar to Caribbean matrifocality. Even though Cuba is often regarded as a patriarchal society, matrifocal kinship coexists with cultural and social tendencies that can be characterized as machista; for instance, Verena Martinez-Alier (1974: 124-130) shows that matrifocality already characterized the family relations of many Cubans during the nineteenth century. Regional, racial, and class differences exist within Cuba and in parts of the Caribbean.

${ }^{6}$ This dichotomy is connected to Mauss's contrast between gift economies and monetized, commodity economies. Gift and monetized economies have been widely discussed (for an overview, see Maurer 2006). Both forms typically co-exist as principles orienting exchanges in a society (Gregory 1982) and they may overlap, entangle, and inform each other in complex ways (e.g., Zelizer 2005).

${ }^{7}$ For a contrasting argument, see Rosendahl (1997) who argues that reciprocity does not form part of the official Cuban socialist state ideology.

${ }^{8}$ My interlocutors practiced both Afro-Cuban and Catholic rituals. I focused on Catholic rituals because their practice varies more over the life course than the practice of Afro-Cuban rituals (see Härkönen 2016).

${ }^{9}$ Sexual "access" does not mean women are seen as lacking sexual desire and agency, but rather women's sexuality offers them "erotic agency" (Wardlow 2006: 232). Habaneros' gendered conceptualization of sexuality emphasizes a view of men as "continuously" desirous for sexual intercourse and as governed by such desires, whereas women are expected to be more "restrained and reasonable" (Härkönen 2016; Lundgren 2011).

10 "Work" can refer to both formal and informal economic activities.

${ }^{11}$ Soon after, Yunior lost his job and Talía distanced herself from him even more.

${ }^{12}$ Yankiel transported dairy products and sold them illegally on the black market. 
${ }^{13}$ While birthdays require extra shows of wealth, Yankiel was also generous with his money during other outings.

${ }^{14}$ A similar idea of respect concerns women, but to a lesser degree. 
